DOI: 10.21005/pif.2020.44.B-09

\title{
VOLUME-SPATIAL COMPOSITIONS OF BUILDINGS POLTAVA OF THE LATE NINETEEN - EARLY TWENTY CENTURIES
}

\section{Tetiana Savchenko}

Postgraduate student, research Assistant

Author's Orcid Number: 0000-0001-6902-392X

Department of Buildings Architecture and Urban Planning, Educational-scientific institute of architecture and construction, National University «Yuriy Kondratyuk Poltava Polytechnics»

\section{ABSTRACT.}

The article presents studies of the formation patterns of the buildings composition in Poltava in the late 19th - early 20th centuries. The main types of volume-spatial compositions and factors that influenced its formation are identified: urban (location in the system of urban development), and functional (typology of buildings). The means of organization of the volume-spatial structure of the buildings of Poltava have been studied.

Key words: three-dimensional composition, frontal construction, compositional scheme. 


\section{INTRODUCTION}

In order to preserve the historical value of the city, its cultural and artistic color, it is necessary to study its architectural heritage. The modern urban environment of the central part of Poltava is formed by architectural objects of different historical epochs. A significant part of them are buildings of the late 19th - early 20th centuries. Their influence on the formation of the three-dimensional composition of the city is quite noticeable. Most of the objects of study are architectural and cultural monuments of local and national importance. They require comprehensive study and preservation. According to G. Osichenko's research, the compositional organization of the city, which was formed at the beginning of the 20th century, is the starting point for solving its reconstruction $(\mathrm{H}$. Osichenko, 2006, p. 41). This conclusion emphasizes the relevance of the study of compositional particularities of architecture of Poltava in the late 19th - early 20th century.

The compositional organization of the buildings of each individual historical epoch reflects its inherent traditions of formation (I. Arauho, 1982, p. 41). Political, economic, cultural, social, natural conditions of society for a certain period of time create urban, functional and stylistic factors in the formation of three-dimensional composition of buildings. In this article the task is to identify the dependence of the compositional organization of buildings of Poltava of the late 19th - early 20th centuries on their location in the system of urban development and functional purpose. The influence of building stylistics on the formation of three-dimensional composition will be considered in detail in the following publications.

An architectural composition is considered as a consistent pattern of volumes (elements of buildings) into a single form (building), which corresponds to its functional purpose. To study the peculiarities of the formation of three-dimensional composition, it is necessary to identify the methods of compositional organization of the form. Methods of architectural composition are divided into three groups: means of organizing the structure of architectural form, harmonization and strengthening of emotional expression (O. Titz, 1976, p. 173). In the research the structural compositional methods of the organization of the form are considered. Identifying the methods of harmonization of architectural composition (proportions and scale) requires a detailed study that goes beyond the article and will be carried out in future works. Methods of strengthening the expressiveness of emotional perception are considered at the structural level of the form organization. The texture and color were left out of consideration, which cannot be fully investigated due to the loss of their authenticity and the lack of archival materials dedicated to this issue.

Methodology. The study was conducted on the basis of architectural drawings and field surveys of buildings in Poltava in the late 19th - early 20th centuries. Structural analysis of the architectural form of the objects of study revealed the patterns of formation of their three-dimensional composition. A comparative analysis of the buildings of Poltava of the studied period established the dependence of their compositional organization on the method of location in the building and functional purpose. Systematization of the obtained results allows to reveal the basic schemes of compositional solutions used in the architecture of Poltava of the end of the 19th - the beginning of the 20th centuries.

State of Knowledge. The basis for determining the compositional features of the architecture of Poltava of the late 19th - early 20th centuries were:

- works are devoted to the laws of organization of architectural composition by I. Araukho, A. Ikonnikov, V. Krynsky, I. Lyamtsov, O. Stepanov, O. Titsa, M. Turkus, F. Chin;

- scientific research of compositional features of Ukrainian architecture of the end of XIX - beginning of XX centuries: Yu. Ivashko - compositional-planning structure of residential, public and industrial buildings of modernism (Yu. Ivashko, 2013, p. 140-153), S. Linda - compositional aspects of Lviv architecture of historicism period (S. Linda, 1999, p. 13-18), O. Morgun - compositional organization of historicism buildings in Odessa, L. Polishchuk - compositional analysis of secession objects of Ivano-Frankivsk, V. Chepelyk - composition and morphology of Ukrainian architectural modernism (V. Chepelyk , 2000, p. 242-256);

- study of compositional features of Poltava architecture - V. Vadimov, G. Osichenko - compositional structures of historical cities (H. Osichenko, 2006, p. 43), L. Kotenko, L. Shevchenko - 
compositional organization of Poltava mansions of the XIX - early XX centuries (L. Shevchenko, 2010, p. 107-110).

There are currently no systematic studies of the three-dimensional composition of the architecture of Poltava of the late 19th and early 20th centuries, so this issue requires a thorough study.

\section{RESULTS OF THE STUDY}

The growth of the city and the increase of its commercial value at the end of the 19th century required the consolidation of buildings and changes in the principles of its organization. Under the influence of the rapid economic development of the city in the late 19th - early 20th centuries, the principle of building streets "solid facade" was proclaimed in the period of classicism, but not realized at that time due to the stable traditions of "manor". The development of the city was carried out taking into account the existing compositional structure and the system of architectural dominants laid down in the previous stages, which fixed the visual compositional axes of the city. As previously noted, the perimeter construction of the quarters with the fixation of intersections introduced in the city contributed to the development of ordinary construction, which directly affected the spatial organization of buildings.

The specific urban situation of Poltava led to the formation of the primary properties of the volumespatial compositions of the studied objects of the city - the size of the architectural form, its geometric structure and the ratio of parts. It was found that the volume-spatial compositions of the buildings of Poltava of the studied period is organized mainly on the basis of elements of the first stereometric group - rectangular parallelepipeds (main volumes of the building, projections, protruding elements, niches). Volumetric and linear elements of other stereometric groups were used alongside them, but they were subordinate. Thus, in the architecture of the city there are elements of the second and third stereometric groups - prisms and pyramids (roofs, towers), bodies of rotation (volumes of buildings, bay windows, niches, domes).

It is revealed that the volume-spatial composition of Poltava buildings of this period is based on:

- dominance of one volume with pronounced subordination of other parts;

- on the nuanced ratio of several volumes (parts of buildings).

The choice of methods of interaction of the elements of the first stereometric group in the composition of city buildings was significantly influenced by their location in the city and the role in the formation of a particular urban space. The analysis of the planning and spatial structure of Poltava of the late 19 th and the early 20th centuries showed the presence of compositional and species connections between the studied objects and structural components of the city, in particular - street, square, crossroads. Thus, the advantage of regular planning, axial perspective and fixation of points of visual perception of buildings contributed to their appropriate placement in the urban structure:

- ordinary (frontal) with the dominance of one volume and focusing on one rectangular face of the parallelepiped (front of the street);

- angular in ordinary buildings with a combination of two equivalent volumes (parallelepipeds) and focusing on the line of their interaction - the intersection;

- separated from other buildings with the dominance of the vertical direction of composition (Fig. 1).

It is determined that the front view of the three-dimensional composition of the buildings of Poltava of the late 19th - early 20th centuries prevailed over the others, which was facilitated by the tendency to continuous facade construction of the streets. Detached buildings in ordinary street buildings lose their deep vector due to the possibility of their visual perception only when moving down the street. The volume-spatial type of the composition of corner buildings of ordinary buildings depends on the point of perception. Thus, when driving on the street, such buildings are perceived frontally, as they create a continuous front with ordinary buildings. When perceiving a building from an intersection (from a corner), it acquires volume, especially due to the accentuation of the cor- 
ners of such buildings with bay windows, gables, domes. This is a common approach in the architecture of city during the study period.

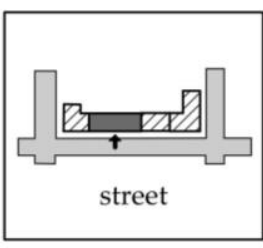

Ordinary (frontal)
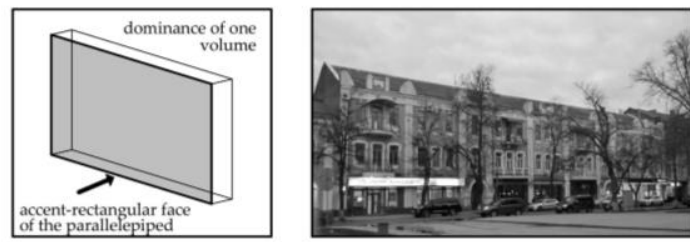

Hohol street 19

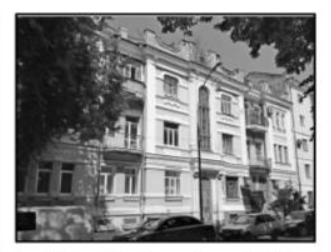

Korolenko street 30

Corner in ordinary buildings
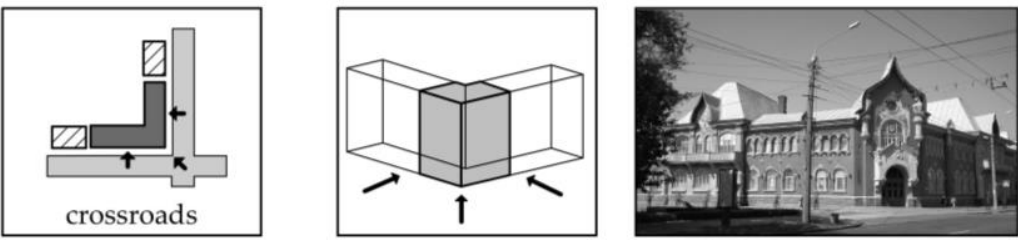

Sobornosti street 39

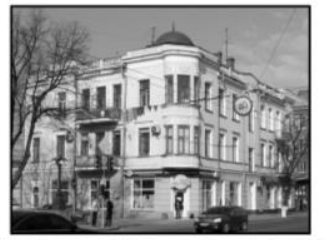

Nebesnoi Sotni street 14/18

Freestanding
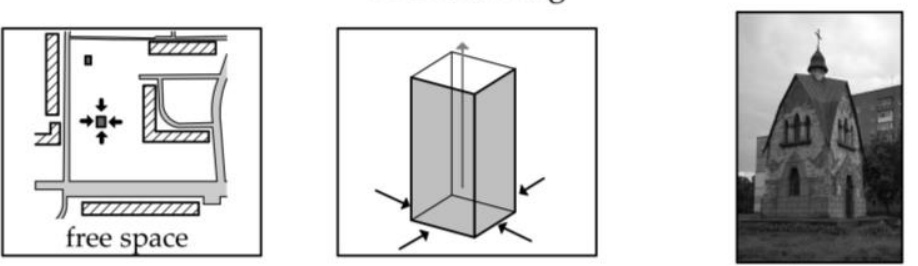

Zinkivska street $16 a$

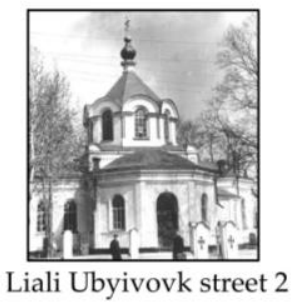

Liali Ubyivovk street 2

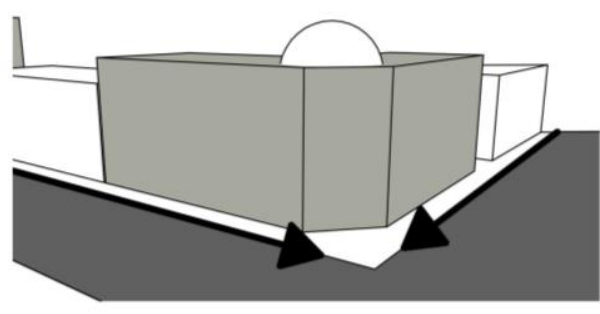

Creating a compositional accent - fixing the intersections of streets with corner buildings

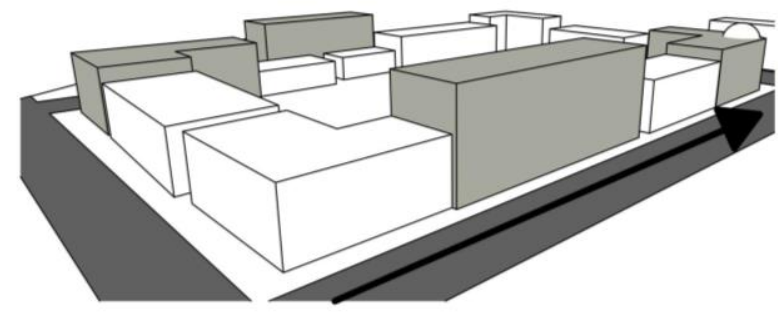

Frontal construction of streets

Fig.1. Compositional and species connections between Poltava buildings in the late 19th - early 20th centuries and structural components of the city. Source: drawings and photo of the author

The volume-spatial type of the composition includes religious buildings (most of which were destroyed), which closed the axial perspectives of the streets and residential and public buildings located on the outskirts of the city or in the middle of the quarters; Miasoiedova St 27/29; Stritenska St, 37a). The location of religious buildings at a distance from other buildings and their use to create compositional dominants of the city gave them special importance, which emphasized their spiritual function (Fig.2) 
The location of the chapel at Zinkivska Street 16 which at that time was a field on the northwestern border of the city, was special. It is due to the historical significance of this place (there was a meeting of peasants with Emperor Nicholai II on the occasion of the 200th anniversary of the Battle of Poltava). The compositional solution of buildings in the middle of the quarters was influenced by the size and shape of the courtyard space. The location of the majority of residential buildings on the outskirts of the city (manor buildings) allowed them to use more freely forms in their volume-spatial composition.

Fig.2 System compositional dominants. Source: of
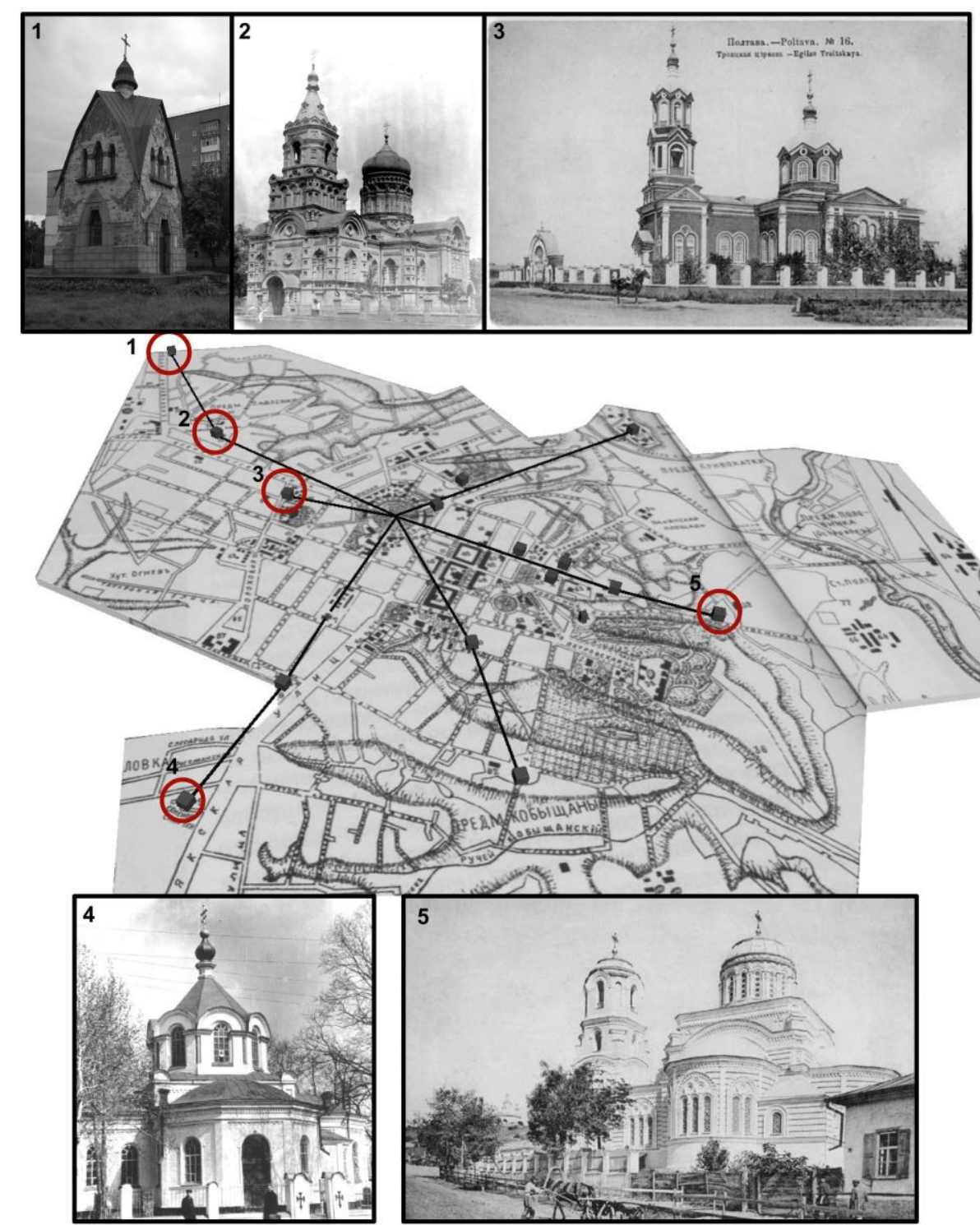

1. Memorial chapel on the site of a peasant camp, 1914, (current state, photo by Savchenko T.)

2. Church of the Intercession, 1903, destroyed in 1946 (postcard of the early 20th century. http://histpol.pl.ua/ru/pamyatniki-istorii-i-arkhitektury/religioznye-sooruzheniya) 3. Holy Trinity Church, 1894, destroyed in the 30's of the 20th century. (postcard of the early 20th century.http://histpol.pl.ua/ru/pamyatniki-istorii-i-arkhitektury/religioznyesooruzheniya)

4. Macarius Church, 1903 (фото сайту https://makariy-sob.church.ua)

5.Church of the Nativity of the Virgin, 1899, destroyed in 1943 (postcard of the early 20th century. http://histpol.pl.ua/ru/pamyatniki-istorii-i-arkhitektury/religioznye-sooruzheniya) 
The study recorded the interactions between the location of buildings in the urban development system, and hence the type of their volume-spatial composition and their functional purpose. Thus, the role of dominants (separated from other buildings) was performed by sacred and some administrative buildings, accents - public (corner in ordinary buildings), background buildings (ordinary, frontal) - residential buildings. This introduced and consolidated the hierarchy of buildings, depending on their importance in the Poltava society of the that period. The expressiveness and character of the three-dimensional solution of architectural objects were created by compositional methods of revealing their form.

The streets were built mainly along the "red lines", which contributed to the achievement of integrity and the formation of the frontality of the composition. To highlight the entrance to the building, a composite technique of displacement of individual parts of buildings (formation of projections) was used, which sometimes led to the formation of the frontal space. Depending on the interaction of the mass of the building and space, the following types of frontality in the formation of the "facade" rectangular face in the composition of architectural objects of Poltava of the late 19th - early 20th centuries (Fig.3) are defined:

- ideal frontality - a single volume of a building or placement of a number of a building volumes in one plane, forming a continuous "facade surface" (Hohol St. 19; Lidova St/ 6; Kotliarevskyi St. 30 , etc.). Such buildings were placed clearly along the "red lines" of the streets, supporting their common building front. Some of them are characterized by a slight relief of the surface due to minor protrusions of architectural elements;

- preservation of general frontality with displacement of separate elements (parts of the building) in the frontal plane (Pylyp Orlyk St. 10-15, Korolenko St. 2). In this case, the deep vector of composition development has no pronounced independence, but on the contrary - is subject to the dominant frontality. This method of compositional solution gave Poltava buildings greater plasticity and expressiveness and contributed to the selection of their main compositional axes. At the same time, the clear placement of the building along the "red lines" of the streets and the extreme boundaries of the plots was preserved;

- creation of frontal space by partial inclusion of a deep vector of composition development in the general frontality of a surface. This method of arranging the building in Poltava had two variants of embodiment: the first - the creation of a space in front of the main entrance of the building (kurdoner), typical of buildings of the "rocker" type (Pyshkin St. 30); 2nd - the location of the part of the building with a deviation from the "red line" of the building (Sobornosti St. 3; Hohol St. 9). A further increase in the activity of the depth vector led to a loss of frontality and a transition to the volume of the composition.

The primary properties formation of the volume-spatial composition of architectural objects in Poltava, namely their main geometric characteristics, was significantly influenced by the width of the section on the front, as well as the functional purpose of the building. Depending on the ratio of height and width, the frontal compositions of buildings were organized according to the following principles (Stepanov, 2007, 124):

- nuanced, with an approximate equality of height and width

This principle of organization of the frontal composition is characteristic of mansions (Yevropeiska St. 3; Hohol St. 9; Korolenko St. 2; Spaska St. 11; Sobornosti St. 3), one-section apartment buildings (Pyshkin St. 40; Kotlyarevskoho St. 30) and public buildings of the city (Sobornosti St. 17 Hohol St. 22).

- contrasting, with a noticeable advantage of width over height (Fig.4).

The most widespread was the frontal composition with the active development of the horizontal vector, which was a characteristic means of compositional organization of apartment buildings in Poltava, especially 2-3 section (Hohol St. 19; Stritenska St. 27, 49, Yevropeiska St. 12, Shevchenko St. 58,) and large public institutions (Sobornosti St. 19, 24/15, 39; Ostrohradskoho, 2; ave. Pershotravnevyi, 10, etc.). 
Placement on the red line

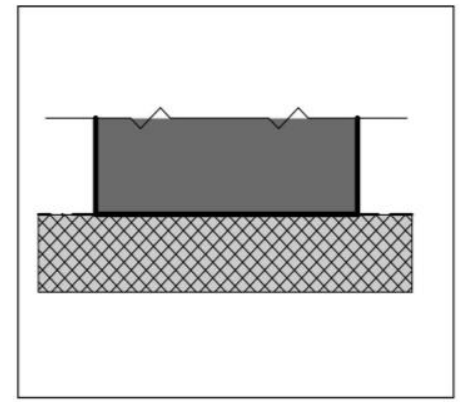

Placement on the red line

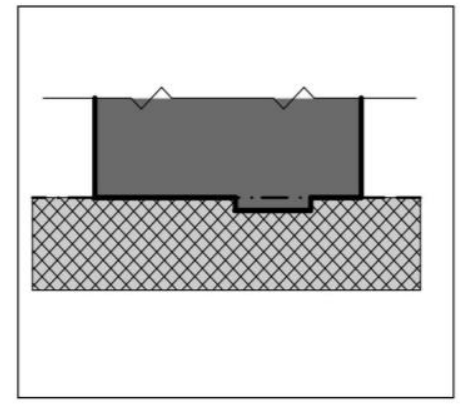

Placement on the red line

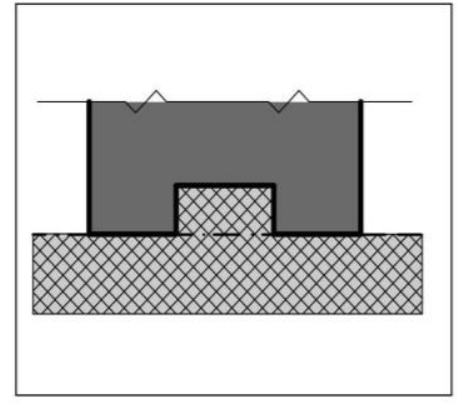

Indent from the red line

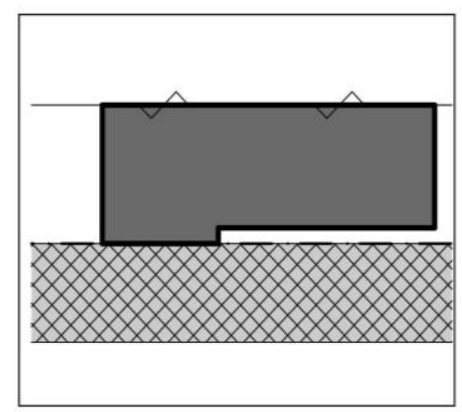

Perfect frontality

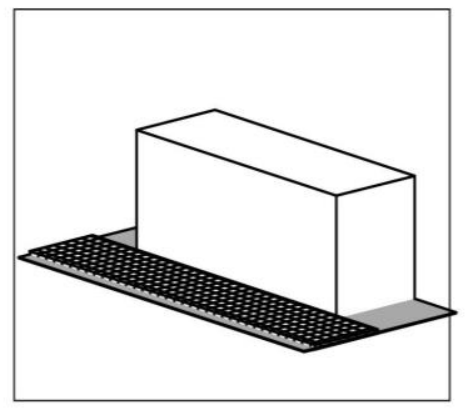

Preservation of frontality

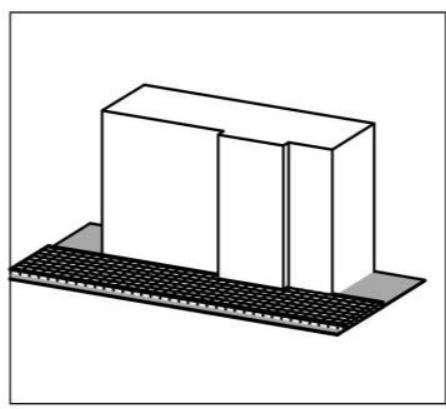

Formation of frontal space creating a kurdoner

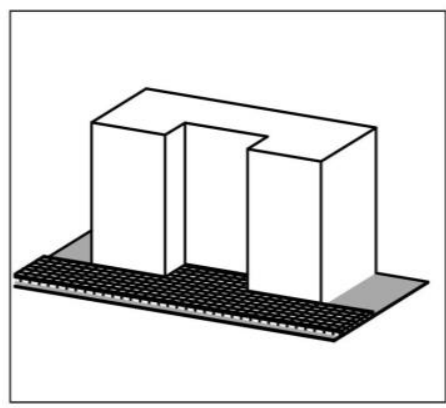

Formation of frontal space indent from the red line

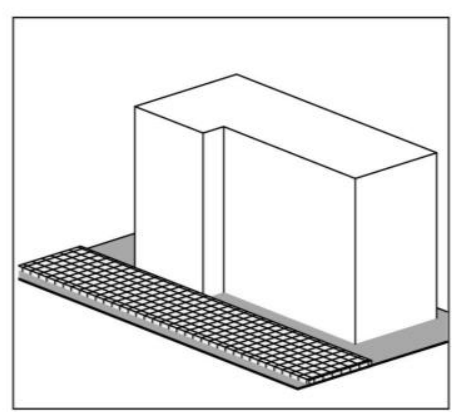

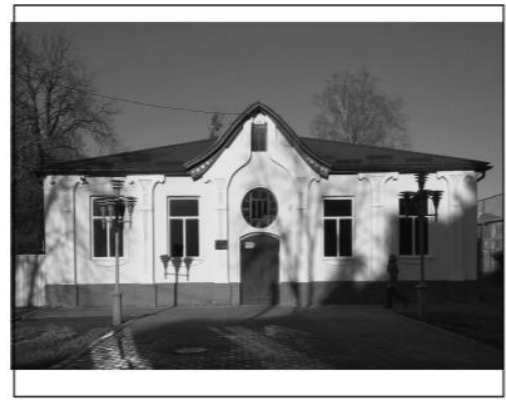

Lidov street, 6

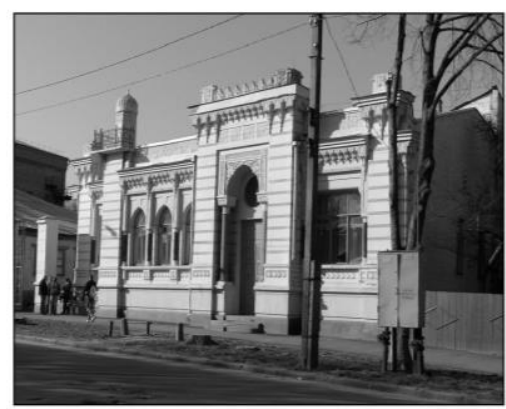

Pylyp Orlyk street, 15

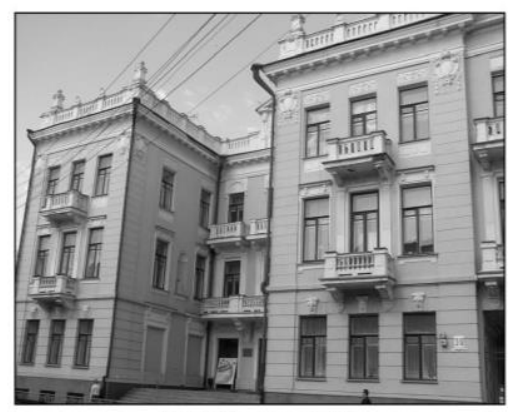

Pyshkin street, 30

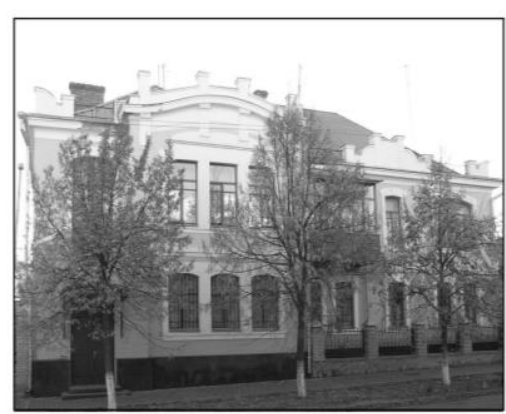

Hoholya street, 9

Fig.3. Interaction of the mass of space of frontal building in the architecture of Poltava in the late 19 - early 20 centu-ries. Source: drawings and photo of the author 
Nuance ratio of height and width
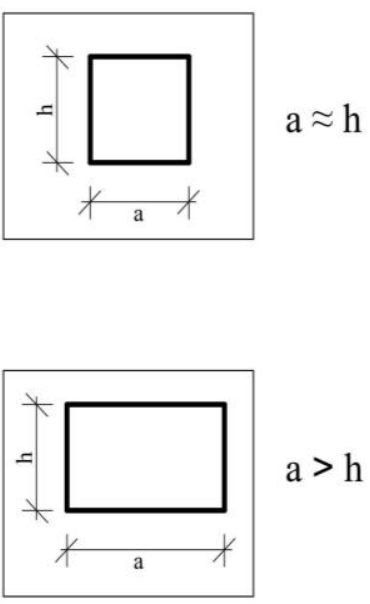

$\mathrm{a}>\mathrm{h}$

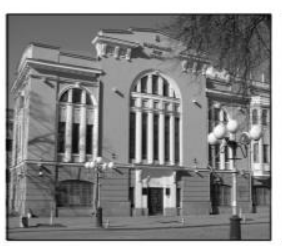

Sobornosty street, 17

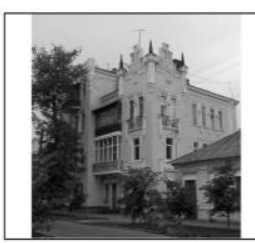

Pyshkin street, 40

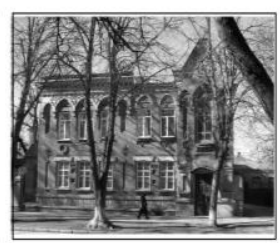

Sobornosty street, 3

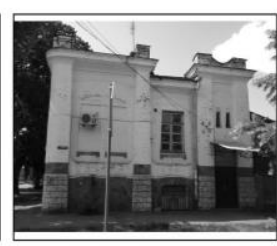

Korolenko street, 2

Contrasting width advantage

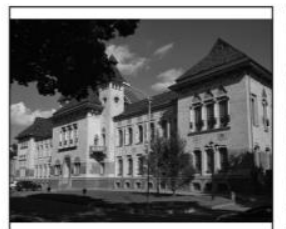

Konstytuciyi street, 2

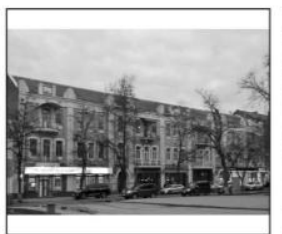

Hohol street, 19

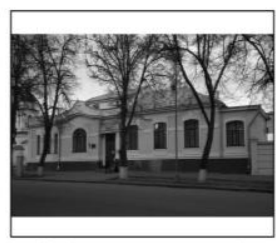

Sobornosty street, 8

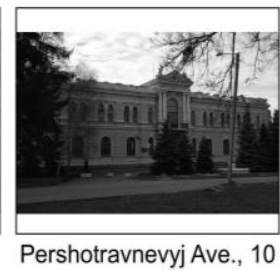

Fig.4. The ratio of height and width of the frontal composition. Source: drawings and photo of the author

The study showed that the predominance of the vertical vector in the frontal composition was not characteristic of the architecture of Poltava of the period under study, because due to its provincial nature the city was built of low, mostly two-, three-storey residential and public buildings. The interaction of the elements that create a volume-spatial composition of the city buildings of the late 19th and early 20th centuries took place using one of the techniques identified during the study (Fig.5):

- placement of elements at a distance in one front plane of the street. In this case, the elements are individual buildings that form ordinary buildings (Hohol St. $5-9 ; 1100$-richchya Poltava St. $2-4$ and Yevropeiska St. 6; Pushkin St. $38-42$ );

- adjacency of elements - separate volumes of one building (Pushkina St. 40);

- interpenetration (incision) of building elements - active compositional interaction of elements in one building (Constitution St. 2; Pushkin St. 18/24, Sobornosti St. 8).

The study found that the predominance of the frontal type of composition in the construction of the city in the late 19th - early 20th centuries concentrates all the means of achieving compositional expression on the solution of the main facades of buildings. Perimeter buildings made it possible to perceive the buildings mainly from the street, so their courtyard facades were solved much more modestly than the main ones. A number of them were completely devoid of decorative characteristics.

The study of the patterns of development of the volume-spatial composition of facades was carried out by identifying the means of compositional organization of form, its structure, harmonization and emotional expressiveness (O. Titz, 1976, p. 173). Therefore, the creation of a holistic and harmonious volume-spatial composition of Poltava buildings was carried out by techniques aimed at revealing of its expressiveness, figurative and semantic meaning. 
Placement of elements (individual buildings) on the detached
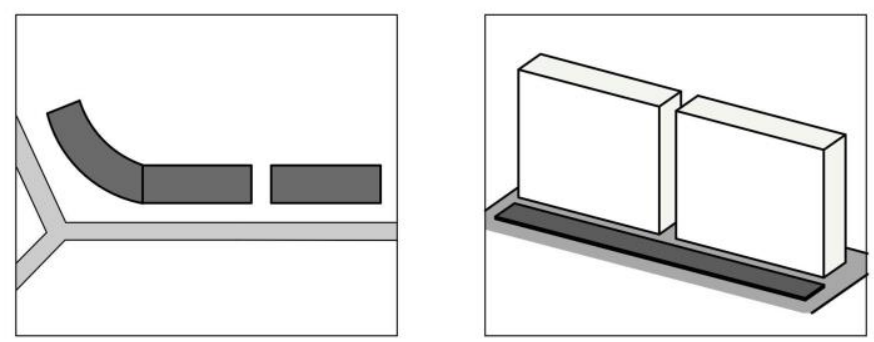

Adjacency of building elements
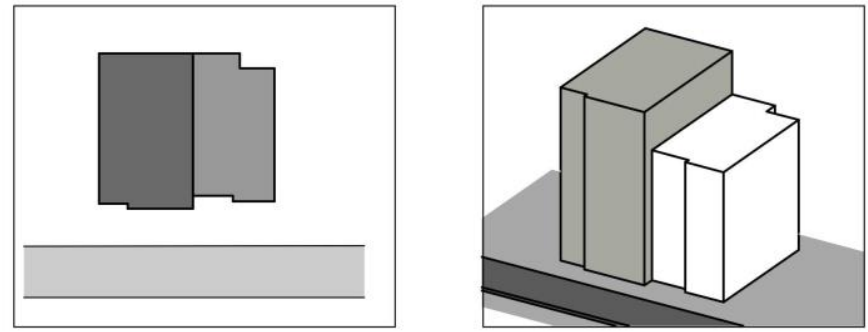

Interpenetration of building elements
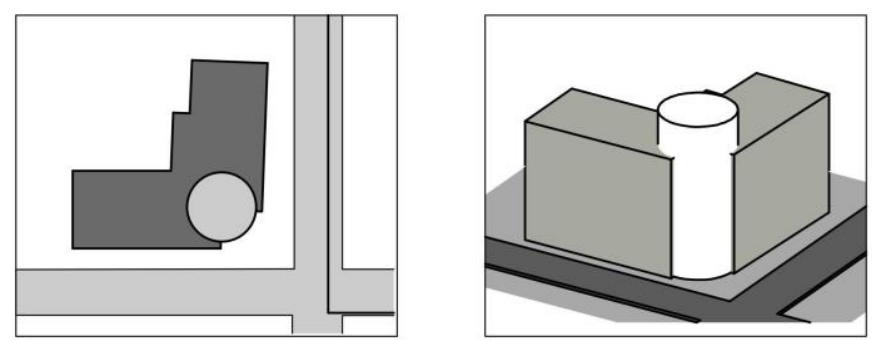

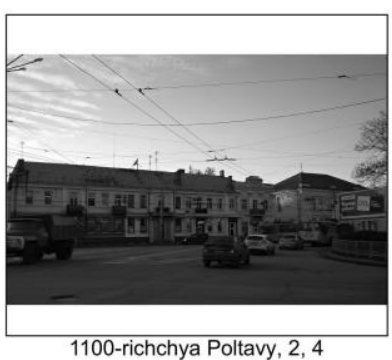

1100-richchya Poltavy, 2, 4

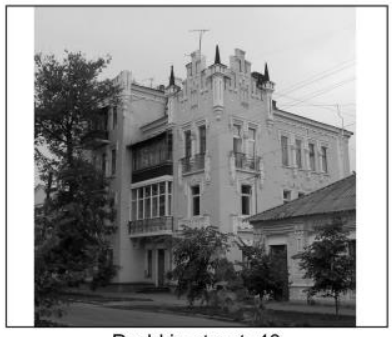

Pyshkin street, 40

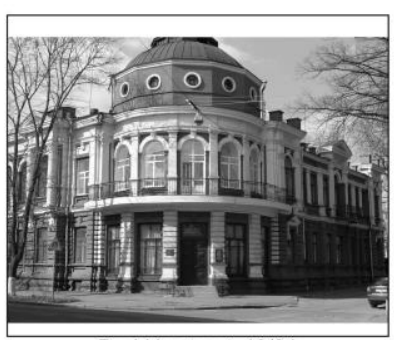

Pyshkin street, $18 / 24$

Fig.5. Types of interaction of three-dimensional composition elements in the architecture of Poltava in the late 19 - early 20 centuries. Source: drawings and photo of the author

The study identifies the means of organizing the volume-spatial composition of buildings in Poltava in the late 19th - early 20th centuries, including:

1. those that are aimed at identifying the general characteristics of the geometric shape and its silhouette;

2. those that had an impact on the organization of divisions of the total volume of the building;

3. those with which the facade composition was formed.

Ad. 1) A characteristic criterion for the patterns development of volume-spatial composition of the studied period in Poltava is the silhouette. The plasticity of the silhouette is created by the outline of the main volumes of buildings and completions of curvilinear and rectilinear shape - tongs, gables, attics, domes, towers, roofs. According to the typology of silhouettes defined by V. Chepelyk (V. Chepelyk, 2000, p. 236) and adapted by Yu. Ivashko for the study of modern objects (Yu. Ivashko, 2013, p. 168), the following types of silhouettes were found in the architecture of Poltava (Fig. 6):

- passive, formed by a simple volume of a parallelepiped and a pyramid of a four-sloped roof (Korolenko St. 2; Kotlyarevskoho St. 8; Pylyp Orlyk St. 18; Shevchenko St. 19). It is peculiar 
mainly for residential manor buildings. Insignificant geometric shapes of protruding elements in the form of low columns did not have a significant impact on the formation of the silhouette;

- underdeveloped, the formation of which was influenced by the protruding gables and risalits. The performances of these elements were more active, but few in number, which gave the silhouette restrained expressiveness. Characteristic of most buildings of the studied period, which is due to the stable influence of classicism in the first and rationalism in the third phases of the evolution of Poltava architecture of the late 19th - early 20th centuries (Sobornosti St. 8, 17; Hohol St. 9; ave. Pershotravnevyi 10; Kotlyarevskoho St. 30). Complications of the silhouette with tongs, gables, towers and the creation of its active plasticity were revealed mainly in the first $(1896$ - 1903) and second $(1903-1914)$ phases, which is associated with the stylistic development of the city architecture of the period under study;

- with active plasticity of completions, the basis for which were clearly protruding gables and roofs of projections. The activity of the development of silhouettes was also enhanced by the multiplicity of these elements. Such a silhouette is typical of houses with stylistic features of the Neo-Renaissance (Sobornosti St. 24/15; Yevropeiska St. 3) and decorative modern (Hohol St. 19; Krychevskoho St. 11; Lidova St. 6);

- developed with active plasticity forceps and tower tops (Pushkina St. 40; Konstitutsii St. 2; Sobornosti St. 39). The activity of such silhouettes was most pronounced also due to the asymmetry of the composition, which gave it a certain dynamics. An active and developed silhouette with tower roofs is characteristic of neo-romanticism (neo-Gothic - Pushkin St. 40; neo-Russian style - Sobornosti St. 39; "Moorish style" - Pylyp Orlyk St. 15), including national orientation - Ukrainian modern (Konstytutsii Street, 2; Zinkivska Street, 16).

The study showed that a very developed silhouette with a large number of tower tops and active plastic tongs, which is found in the architecture of major centers of modern Ukraine, is not typical for the architecture of Poltava. At the third phases of development, the silhouette is somewhat simplified, because this stage was not characterized by neo-styles (except neoclassicism), and the development of decorative modernism was significantly influenced by rationalism.

Ad. 2) The main method of achieving the expressiveness of the front surface of buildings in Poltava in the late 19th - early 20th centuries is its metro-rhythmic organization of the main divisions. The study revealed continuous horizontal and vertical divisions of buildings, recesses and overhangs.

The main means that participated in the metro-rhythmic organization of the front surface of buildings were: columns, blades, pilasters, cornices, niches, ledges, risalits, mezzanine and window sills. Metro-rhythmic structure of the main facades of buildings of Poltava of the studied period differs in specificity of stylistic directions which define advantage of this or that.

Ad. 3) The development of Poltava of this period is dominated by symmetry. The asymmetry of the volumetric-spatial solution of buildings is much less common, which is due to the strong influence of the classicist traditions of the previous period. Depending on the symmetrical or asymmetrical solution of facades and the number of composite axes, we distinguish the following composite schemes of buildings of Poltava of the studied period (Fig.7):

- isosceles without highlighting the axis;

- central axial symmetrical with one axis;

- central axial symmetrical with three axes;

- "rocker" - biaxial or triaxial with accentuation of the lateral axes;

- asymmetric ordinary building;

- asymmetric corner building.

The equal accent facade did not have pronounced compositional accents. Quite often such a compositional scheme was used to solve the facades of corner buildings of the city, in particular - on Shevchenko St. 13, 14, 19 and Pylyp Orlyk St. 18. Its use helped to strengthen the dominant role of the corner of the building (Nebesna Sotnia St. 9/17; Pushkin St. 27). 
Passive silhouette
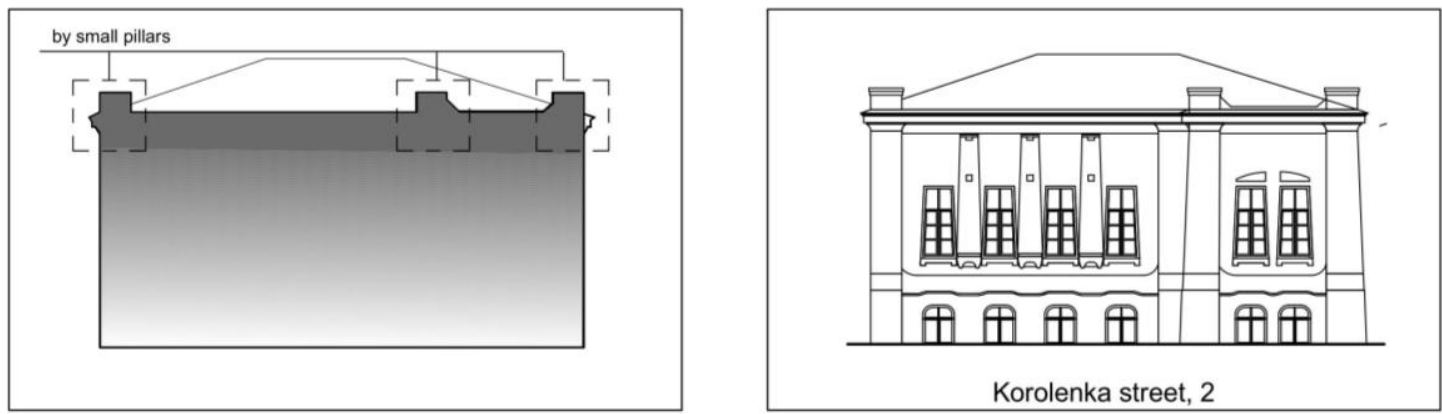

Underdeveloped silhouette
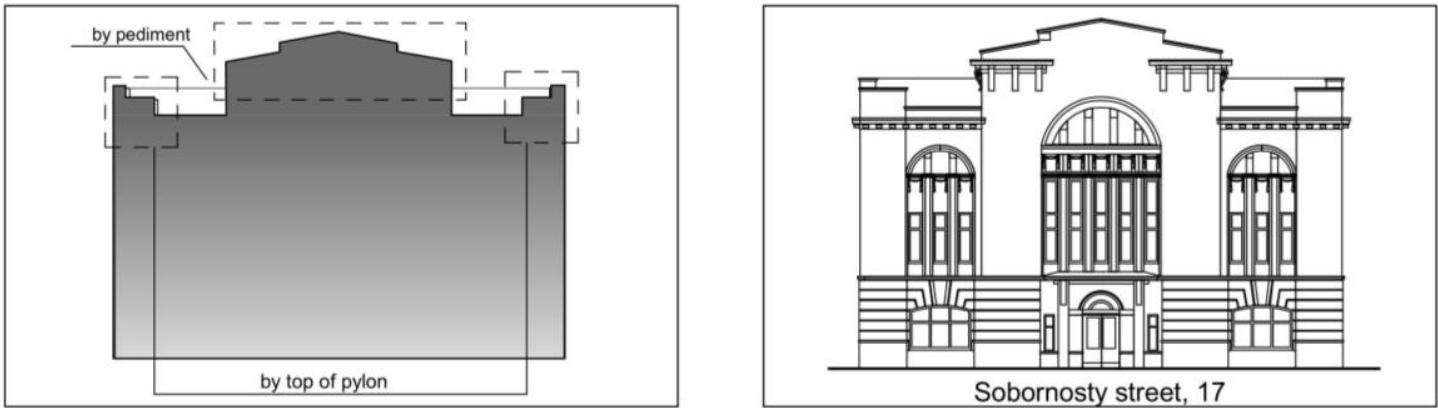

Silhouette with active plasticity completions
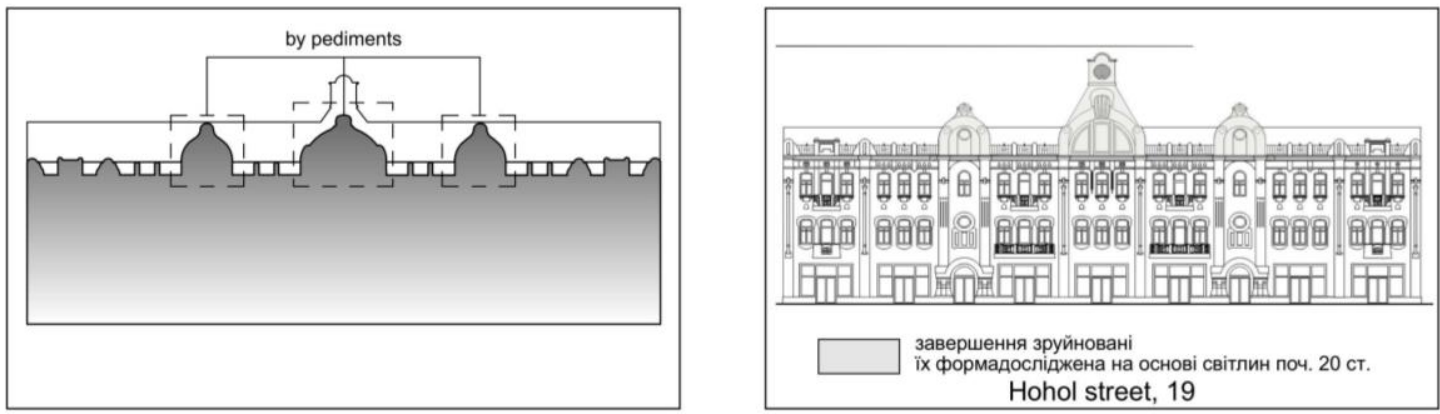

Developed silhouette with active plasticity forceps and tower tops
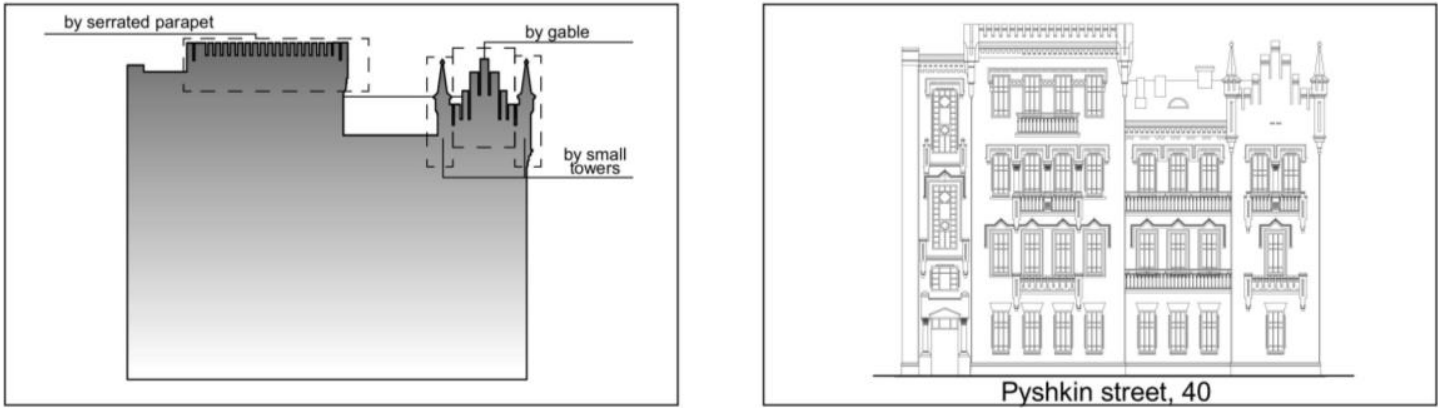

Fig.6. Types of silhouettes of buildings in the architecture of Poltava in the late 19th - early 20th centuries . Source: drawings and photo of the author 
Equivalent
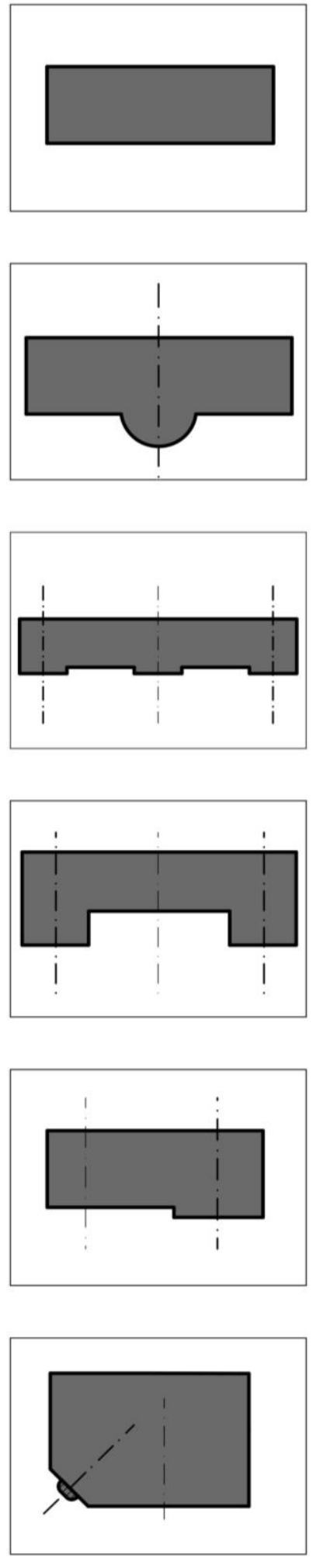

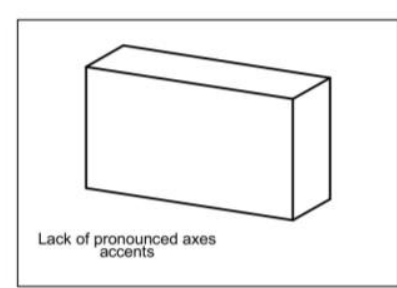

Uniaxial centrally symmetrical

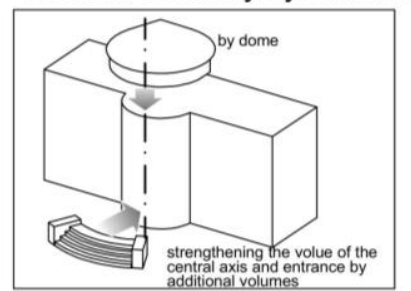

Central semimetric trioxial
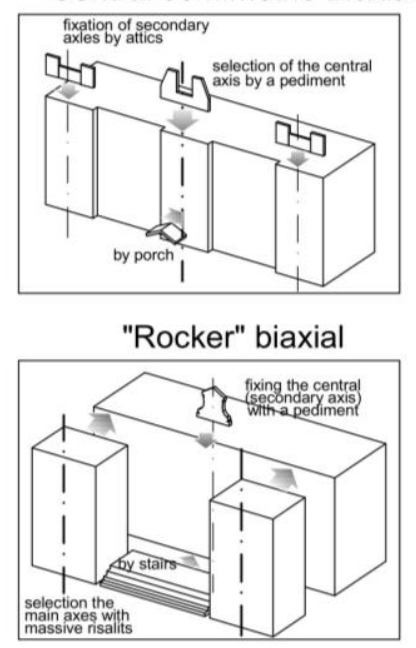

Asymmetric in ordinary buildings

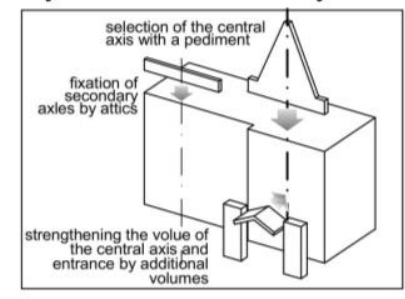

Asymmetric angular

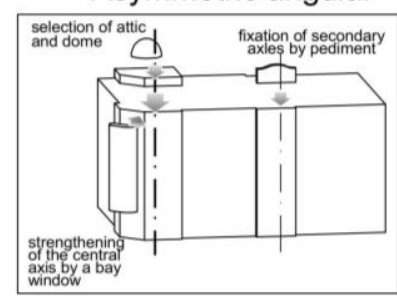

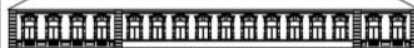

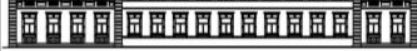

Shevchenko street, 19

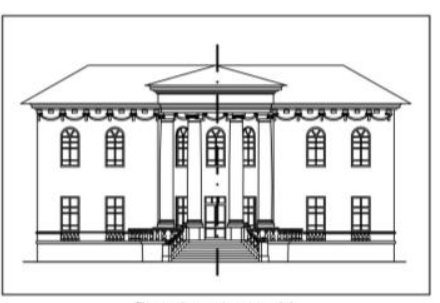

Spaska street, 11
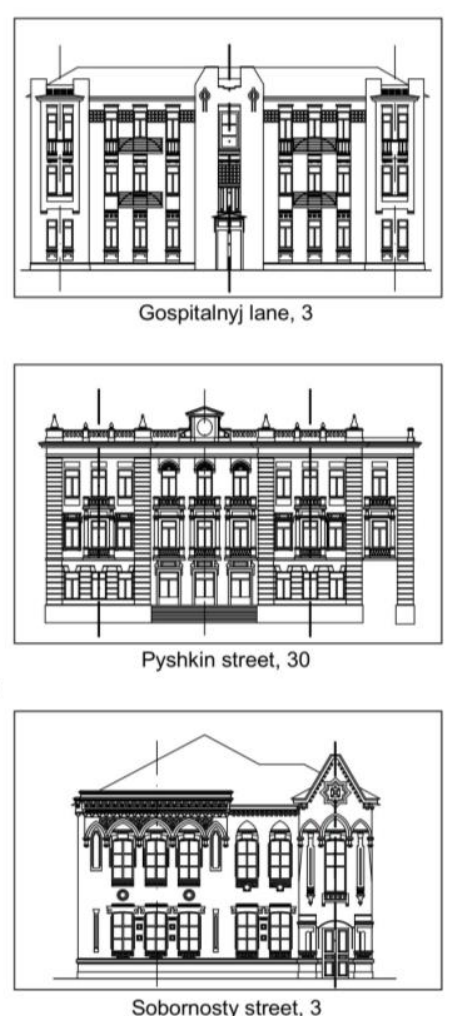

Sobornosty street, 3

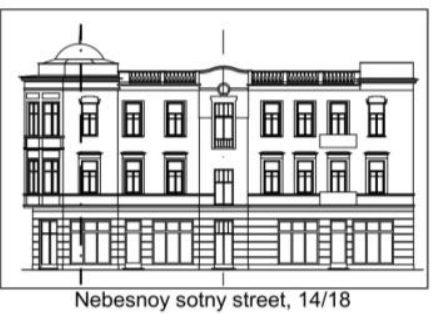

Fig.7. Types of silhouettes of buildings in the architecture of Poltava in the late 19th - early 20th centuries . Source: drawings and photo of the author 
The central axial symmetrical scheme of facades became the most widespread in the architecture of public and residential buildings of Poltava of the studied period. The accentuation of the central axis emphasized the compositional significance of the main entrance of the building. Depending on the number of axes, such a compositional scheme is embodied in the architecture of the city in uniaxial and triaxial versions. The three-axis symmetrical composition dominates among the studied objects (Pershotravnevyi Ave. 10; Kotlyarevskoho St. 30; Hospital Lane 3). Accentuation of axes was carried out at the expense of projections. The lateral axes were subordinate to the central one. It was found that uniaxial symmetry is characteristic of city buildings with a small length of facades. Among them are mansions (Lidova St. 6; Spaska St. 11), public buildings (Sobornosti St. 17). The analysis of the studied objects showed that the centrally axial symmetrical compositional scheme of solving their main facades prevailed in the buildings of classical and rationalist trends, as well as in the architecture of profitable buildings of decorative modern, located in ordinary buildings. In the spread of this compositional scheme in the architectural objects of Poltava the influence of the previous epoch is noticeable, namely - the methods of classicism.

The "rocker" compositional scheme of the organization of facades of buildings is built on the principle of accentuation of lateral axes. Even in the presence of a central axis, it is given secondary importance. The "backstage" of the facade was formed by lateral projections. Their main compositional role is to enrich the plasticity of the facade due to the change of its metric-rhythmic organization (Hohol St. 7; Shevchenko St. 62). Most often, such projections had a small depth, so this method of achieving compositional expressiveness did not violate the integrity of the facade and its frontality. Increasing the depth of the protrusion of the projections creates a frontal space in front of the central part of the building and gives it volume (Pushkin St. 30). This compositional scheme is characteristic of the Neo-Renaissance.

The asymmetric scheme of an ordinary building is typical for the studied objects with a small width of the front surface, mainly for residential purposes (more often - mansions, less often - apartment buildings). The asymmetry was created mainly by the lateral risalit, in which the main entrance to the building was usually organized. To enhance the compositional expressiveness of the risalits had an active completion - a tongs or an attic. This compositional scheme is characteristic of the neo-romantic direction, represented by mansions at the addresses: Sobornosti St. 3; Pylyp Orlyk St. 15; Stritenska St. 37a), an apartment house on the Pushkin St. 40 and mansions of decorative modern on the Hohol St. 9; Sobornosti St. 8, Krychevskoho St. 11; Kozaka, 8.

There are isolated examples of such a reception in the architectural objects of the classical direction, such as - a mansion on the Stritenska St. 43; and an apartment house on the Pushkin street 6a. In corner buildings, an asymmetrical facade is created by transferring the main composite axis to the corner. It is the corner that becomes the center of the building's composition and acts as an urban accent. Each of the corner facades (at the corner of the streets) had one of the variants of the compositional scheme considered above. The study of the architecture of Poltava in the late 19th - early 20th centuries allowed to identify options for solving the angle in buildings (Fig.8):

- without changing its configuration - a simple solution of the angle (Shevchenko St., 14; Shevchenko St. 19; Pylyp Orlyk St., 18), or accentuation of its release (Korolenko St., 2; Pylyp Orlyk St., 11)

- "cutting" the corner in a straight line with the formation of the third (angular) facade (Sobornosti St. 19; Sobornosti St. 39; Nebesnaya Sotna St. 9/17; Pushkin St. 16; Nezalezhnosti Square 20; Sobornosti St. 29/15; Stritenska St. 35; Lidova St. 12);

- $\quad$ "rounding" of the corner (Pushkin St. 18/28; Yevropeiska St. 6; Yevropeiska St. 65).

The development of the compositional organization of the facades of the architectural objects of Poltava of the studied period also took place under the influence of the dominant stylistic trends. Thus, the spread of three-axis symmetry in the first phase of the evolution of urban architecture reveals a close connection with the previous period. The appearance of asymmetrical buildings of the neo-romantic direction indicates the approach of changes in stylistic and compositional development. The second phase revealed the greatest changes in the compositional solution of buildings, as at this time there were the most significant international influences of Romanticism and Modern. The study revealed changes in attempts to confront symmetry and balance of compositio- 
nal solutions, which manifested themselves in the application of asymmetry. The rationalism of the third phase and the spread of neoclassicism led to the restoration of the dominance of symmetry, which was more in line with the principles of these stylistic trends (Fig.9).

No configuration change
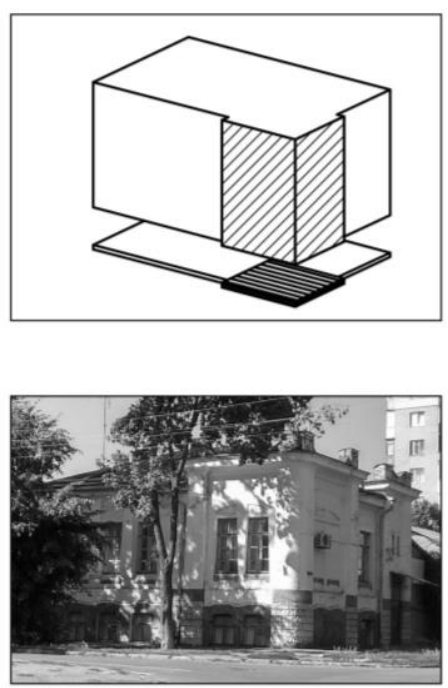

Korolenko street, 2

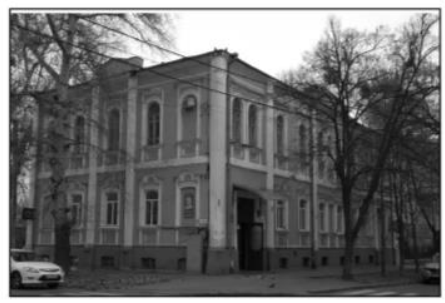

Pylyp Orlyk street, 18

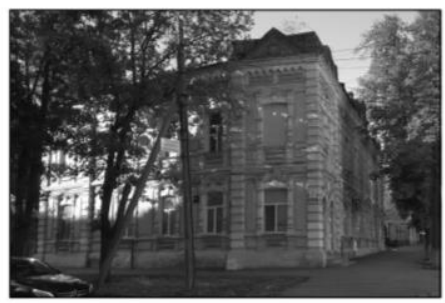

Pylyp Orlyk street, 11
Cutting the corner
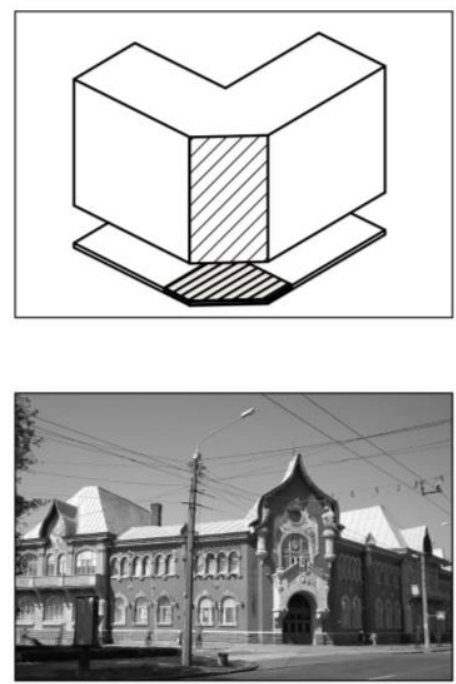

Sobornosty street, 39

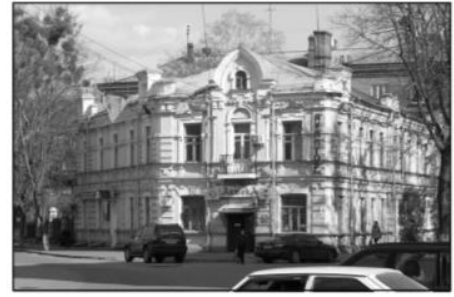

Pyshkin street, 16

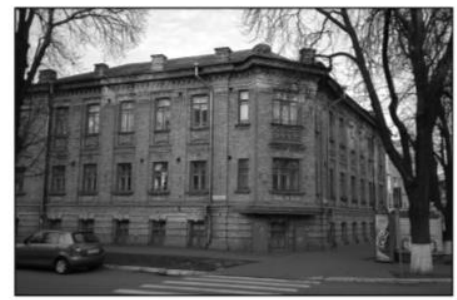

Ostrohradskyi street, 2
"Rounding" the corner
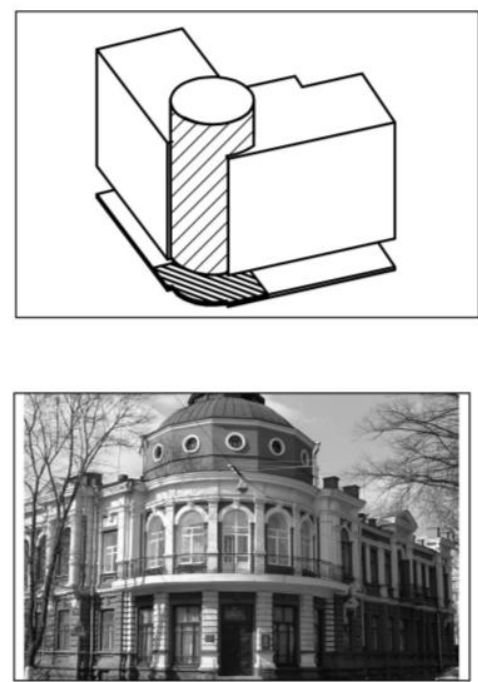

Pyshkin street, 18/24

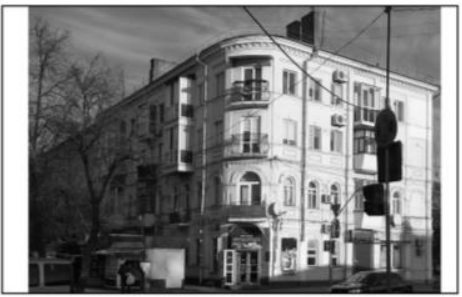

Yevropeiska street, 65

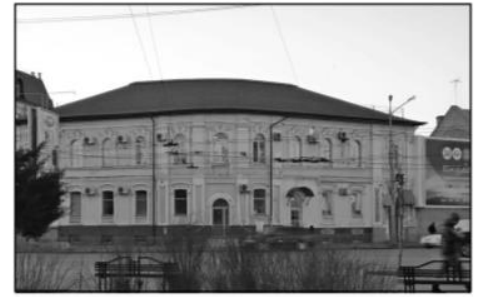

Yevropeiska street, 6

Fig. 8. Solving the angle of the building . Source: drawings and photo of the author

The analysis of the objects showed that the main entrance was the compositional center of most of the buildings in Poltava during the study period. It is located mainly on the main axis of the building, except for the "rocker" scheme of the facade, and corner buildings, where the active angular axis does not always fix the location of the main entrance (Nebesna Sotnia St. 24/15, Korolenko St. 2). The following compositional techniques were used to accentuate the main entrance and enhance its compositional expressiveness in Poltava architectural objects: 
- active completion of the main entrance with a pediment, gable or attic (Stritenska St. 49; Lidova St. 6; Sobornosti St. 3; Sobornosti St. 24/15);

- solution of the main entrance in the form of an additional volume - a portal or portico (Pershotravnevyi Ave. 10; Kotlyarevskoho St. 30; Spaska St. 11.)

- placement of original openings at the main entrance - windows, doors - usually larger than others (Sobornosti St. 17; Hohol St. 22; Pushkina St. 98; Stritenska St. 27)

- decoration of the entrance group with large decor (Sobornosti St. 39; Hohol St. 19).

Fig.9 Development compositional organization of facades of Poltava in the late 19th - early 20th centuries. Source: drawings of the author
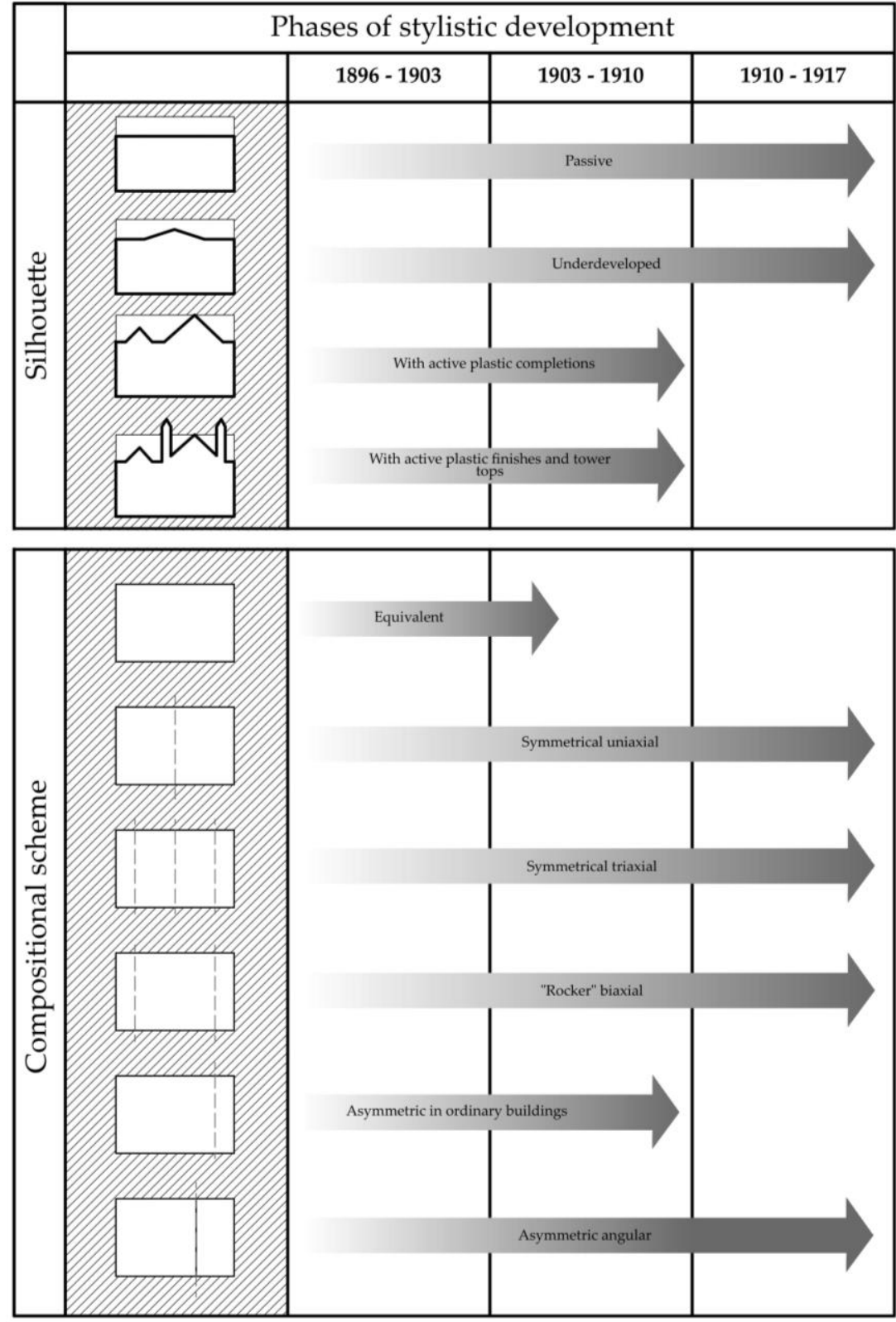

Within the limits of research of compositional construction of buildings of Poltava means of harmonization of their architectural forms are revealed. They are important components of achieving of 
the one of the main aesthetic qualities of buildings - proportionality, which expresses the relationship of architectural form with the environment, man and the conformity of the form to its parts. Among the means of harmonization found in the architectural solution of Poltava buildings of the studied period, the most effective were the architectural scale and proportional patterns.

The architectural scale expresses the conformity of the architectural object to the environment, its ideological and artistic meaning and function. It depends on the physical size of the buildings, the main divisions of the architectural form and its saturation with details. The buildings of Poltava of the late 19th - early 20th centuries at that time were the bulk of the city's buildings and did not exceed three floors. Therefore, one of the features of the architecture of the city of this period is its coexistence with man and the environment. The fragmentation of the main form by architectural elements and their size form a small or large architectural scale of buildings. The combination of small and large scale leads to different scales.

The research revealed that the architecture of Poltava is characterized by small scale and variety. This scale prevails in the buildings of the Neo-Renaissance, decorative Modern and NeoRomanticism. In the Neo-Renaissance, a small scale is formed due to the use of a large number of decorative details, horizontal divisions of the wall surface with rusts and belts, small window openings. Small-scale prevails in the buildings of decorative modern due to their saturation with architectural details. Vertical divisions into several floors (blades, bay windows, risers), large tongs and windows of the first floors of some buildings increased the scale of the building, but significant detalization changed their large scale.

Sometimes to identify the functional purpose of the building and its importance in the building on a general small-scale background used massive elements, such as to highlight the main entrance. Thus, in the building of the Zemelnyi Bank (Pervomaiskyi Avy. 10) the main entrance is separated by a massive portico on the second floor. Neo-romantic trends in the city are characterized by the use of a large number of decorative elements that crush the facades, but against their background often appear large tongs and gables. Thus, in the building of the Derzhavnyi ta Selianskyi Bank (Sobornosti St. 39) a large tongs, massive decorative elements, large windows, and a massive entrance portico were used to strengthen the entrance group. All this in combination with small decorative elements, plasticsty decorative panels, paintings and majolica create some variety of composition of the building.

Large-scale construction was little used in the city's buildings, as rationalism with its almost complete absence of details and large areas of glazing did not become widespread here. The building of the Russian Bank for Foreign Trade (Sobornosti St. 17) belongs to a large architectural scale. The house has a relatively small physical size, but the use of large-scale main divisions increases its height and massiveness, which expresses its social significance and function.

The scale is typical for the buildings of the Ukrainian Modern of Poltava, represented primarily by the Poltava Provincial Zemstvo. It is manifested in large articulations of risalits, massive entrance portal, grouping of windows. In towers it was combined with small articulations of the wall surface with blades, detailing of multi-tiered finishes, details of decorative painting. The dependence of the scale of the building on the levels of its perception from different points in the urban development system is clearly expressed at this object. Thus, at a distance is perceived mostly massive largescale volumes, which demonstrate the importance of the building in society, and when approached, the elegance of details and decorativeness of traditional folk ornaments opens.

The diversity is also inherent in the objects of rationalist modernism of the city of the late 19th early 20th centuries. A small scale is created by a system of vertical divisions of the wall surface with blades, and a large scale is created by the entrance group, expressed by a tongs and quite often by large windows of the stairwell.

In the buildings of Poltava of the studied period the proportional construction of the main facades of all stylistic directions is revealed. According to the study of Yu. Ivashko, decorative modernism is not characterized by a clear proportional organization, due to its expressiveness, asymmetry and lack of order (Yu. Ivashko, 2013, p. 172 - 173), but in the architecture of Poltava in this period such a pattern did not appear. This may be due primarily to the strong influence of classicist traditions, 
its proportional structure, and the absence of clear manifestations of irrationalism. Among the methods of proportional organization in town buildings revealed:

- application of the "golden section" and its derivative ratios;

- proportioning on the basis of the diagonal of the square, which is equal to the width or height of the facade;

- proportioning on the basis of the root triangle;

- the method of inscribed and described squares (Fig.10).

The analysis of the objects of Poltava research revealed proportional dependences between the main divisions of the facade, the width and height of the building, the location of the main axes. It was noticed that the choice of proportioning method depended on the style direction and the author of the project. Thus, in the works of the architect V. Vesseli the proportions of the "inaccurate" square 2: $\sqrt{5}$ were used - in the profitable house of Pertsovich (1890, Pushkin St. 40) in the neo-Gothic style and the house of Zeckel (1905, Nebesnaya Sotni St. 14/18) with stylistic features of classicist modernism. This relationship is found between the main divisions of the building. In Lukyanovich's mansion (1906, Hohol St. 9; decorative Modern), the architect used the ratio of the root rectangle 1: $\sqrt{3}$, which is found in the location of the main axis and between the main divisions of the buildings. The method of squares and its diagonals was used by P. Klein both in the objects of decorative Modern (apartment house Lieshcha, 1905, Hohol St. 19) and rationalist (Gurevich's mansion, 1905, Stritenska St. 35).

The method of squares and its diagonals is found in the construction of Ukrainian Modern buildings. So, in the house of the Poltava provincial zemstvo the square with the party equal to width of the main risalit of the building is taken as a basis of a proportional structure. The module for the construction of the chapel on Zinkivska is the width of the facade in its lower part. The height of the chapel has a three-hour division, based on a certain module (Yu. Ivashko, 2013, p. 173). In the neoclassical building of the Russian Bank for Foreign Trade (1912, Sobornosti St. 17), a method of proportioning with the help of inscribed and described squares in the division of axes and vertical divisions was discovered. In this case, the proportional division of the main volume of the building is expressed in its planning solution.

The above gives grounds to state the similarity of the proportional organization of buildings of different styles and its affinity with the previous period of classicism, which once again confirms the role of architectural details in the formation of their volume-spatial composition and stylistic solutions.

\section{CONCLUSION}

The volume-spatial solution of Poltava buildings of the late 19th - early 20th centuries depended on the location of urban development and functional purpose. In the architecture of Poltava of the studied period the following means of compositional organization of the form are revealed:

- nuance and contrast ratio of height and width;

- the use of rectilinear and curvilinear elements to create the silhouette of the building, which was created by one of the types: passive; underdeveloped; silhouette with active plastic completions, developed silhouette with active plastic tongs and tower tops;

- formation of a facade according to one of the compositional schemes: equal-accent facade without axis selection; central axial symmetrical facade (uniaxial, triaxial); " curtain backstage " - triaxial with accentuation of lateral axes; asymmetrical facade of an ordinary building; asymmetrical facade of the corner building;

- selection of compositional centers and accents;

- division of facades by architectural elements. 


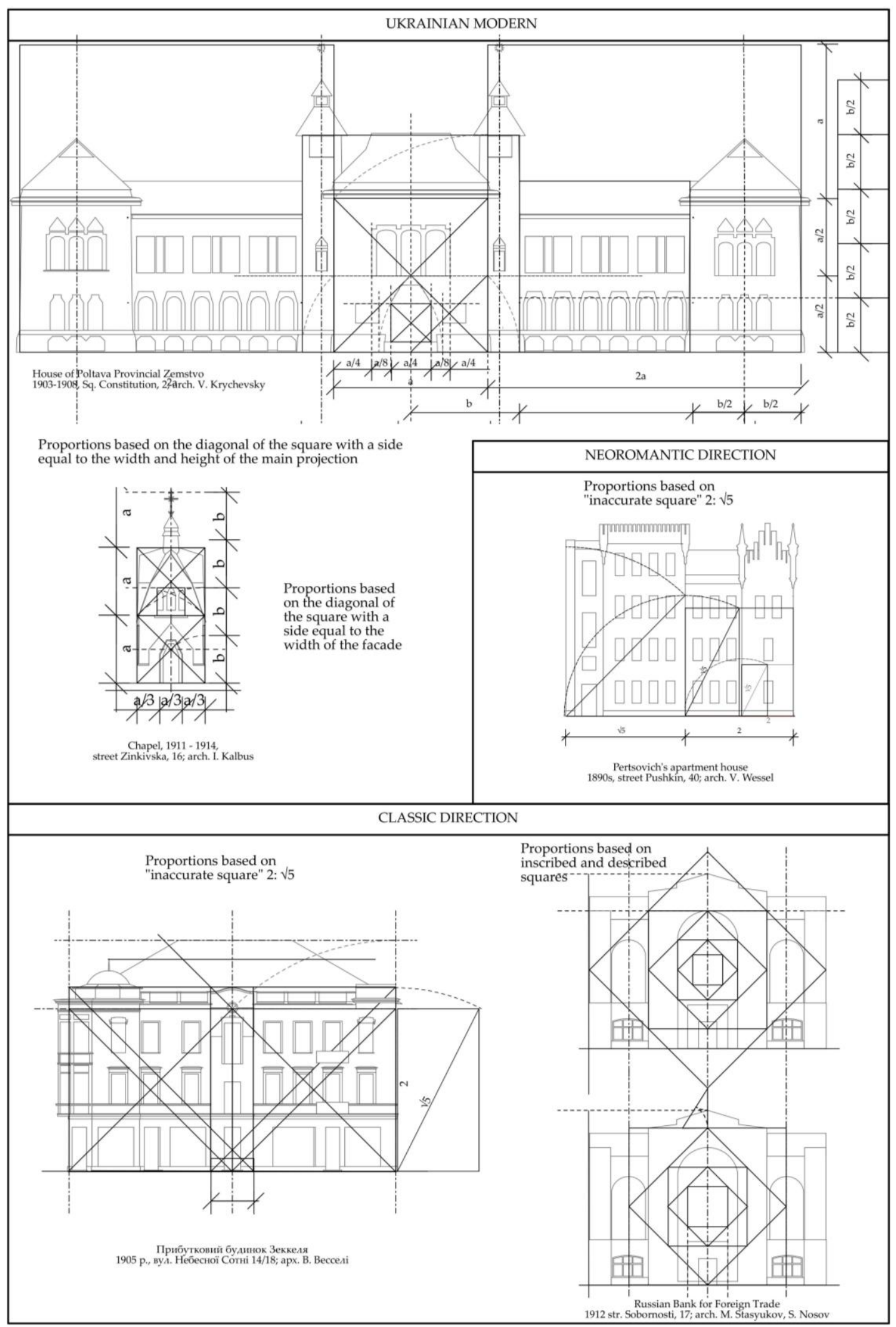

Fig. 10. Examples of proportional construction of facades of buildings of Poltava in the late 19th - early 20th centuries. Source: drawings of the author 


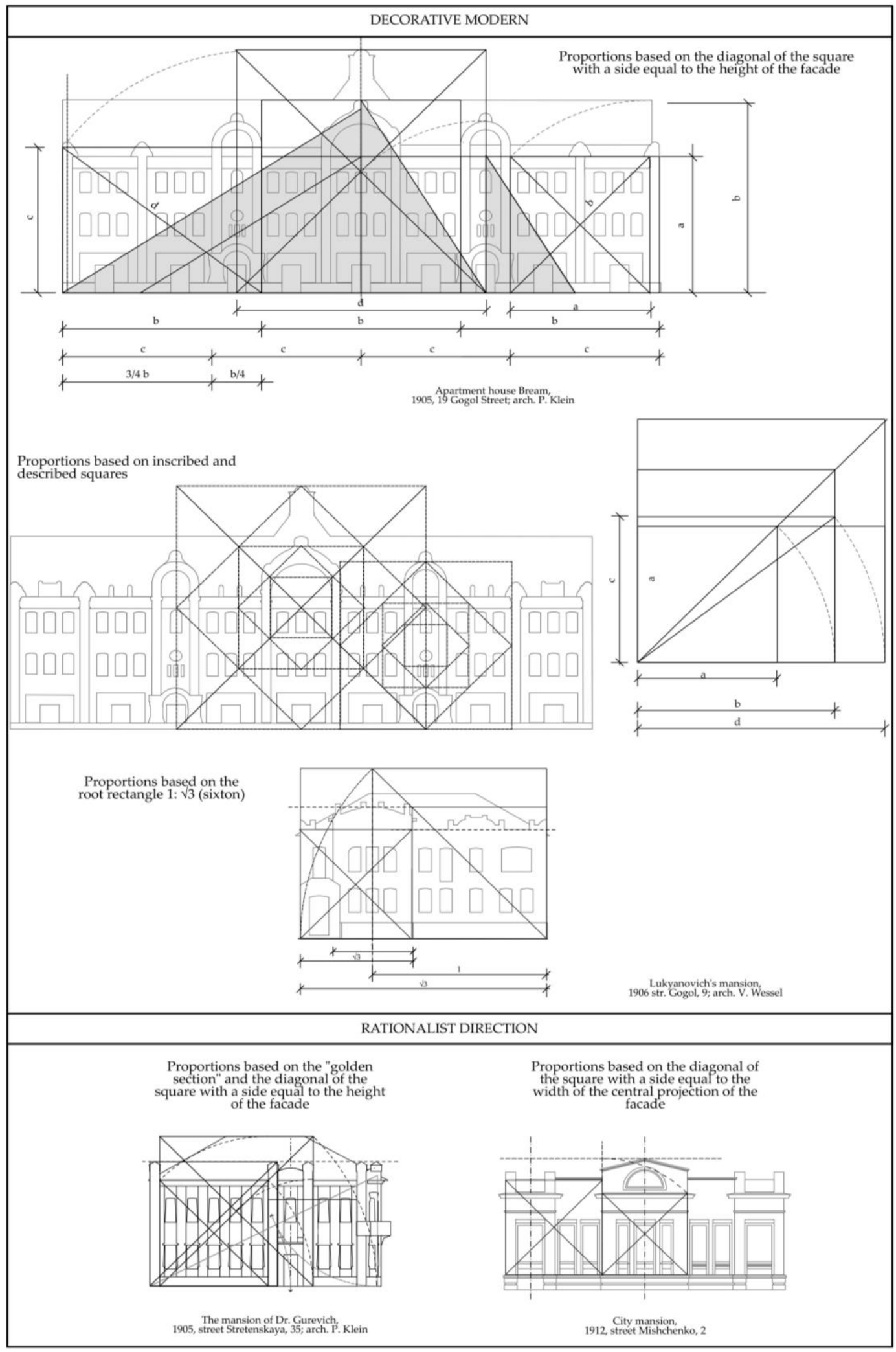

Fig.10. Examples of proportional construction of facades of buildings of Poltava in the late 19th - early 20th centuries. Source: drawings of the author 
The selected factors and means of organization of the composition determined its features:

- the advantage of the frontal composition in the three-dimensional organization of buildings;

- flatness of facades, existing protrusions of facade planes were insignificant;

- different facades, a sharp difference in the solution of the main facade in comparison with the others;

- creation of an active silhouette of the building due to the completions, mainly tongs and gables. Unfortunately, a significant number of them were lost during the Second World War and were not restored;

- the advantage of symmetry as a composite means of organizing the facade plane. The active use of three-axis composite schemes of facades demonstrated a close connection

Further areas of research are to identify the features of the planning organization, the influence of stylistics on the compositional solution and the study of the means of harmonization of buildings in Poltava of the studied period.

\section{BIBLIOGRAPHY}

Arauho I. Arhitekturnaya kompoziciya. Vysshaya shkola, Moscow, 1982.

Chepelyk V. Ukrainskyi arkhitekturnyi modern [upor. Z.Moiseienko-Chepelyk]. KNUBA, Kyiv, 2000.

Ivashko Yu.: Osnovy styleutvorennia modernu v arkhitekturi Ukrainy (kinets 19 - pochatok 20 stolittia), dys. dra arkhit. Kyiv, KNUBA, 2013.

Lamcov I., Turkus M. Elementy arhitekturnoj kompozicii. Glavnaya redakciya stroitelnoj literatury, Moscow, 1938.

Linda S. Stylistychni ta arkhitekturno-kompozytsiini aspekty rozvytku arkhitektury Ivova periodu istoryzmu u k. 19 - poch. 20 st., avtoref. dys. na zdobuttya nauk. stupenya kand. Arh. Lviv, 1999.

Osichenko H. Metodichni osnovi rekonstrukciyi kompozicijnih struktur istorichnih mist (na prik-ladi mist Centralnoyi Ukrayini): dis. na zdobuttya nauk. stupenya kand. arh. Harkiv, 2006.

Shevchenko L. Ob'yemno - prostorova organizaciya poltavskih osobnyakiv 19 - na pochatku 20 st. Tradiciyi ta novaciyi u vishij arhitekturno-hudozhnij osviti: zb. nauk. pr., Harkiv, 2010.

Stepanov A. Obyomno-prostranstvennaya kompoziciya: Uchebnik dlya vuzov. Arhitektura - S, Moscow, 2007

Tic A. Osnovy arhitekturnoj kompozicii i proektirovaniya. Vysha shkola. Kyiv, 1976.

\section{AUTHOR'S NOTE}

Tetiana Savchenko, Postgraduate student, Department of Buildings Architecture and Urban Planning National University "Yuriy Kondratyuk Poltava Polytechnics». The main area of research: stylistic and compositional features of architectural development, preservation of architectural heritage.

Contact | Kontakt: stv-26@ukr.net 